\title{
The Instrumentation and Participatory Outcomes of Web 2.0 Technology as an Interactive E-Governance Platform towards Achieving Sustainable City Visions in Nigeria
}

\author{
Achuenu, Ache Stella \\ Department of Urban and Regional Planning, University of Jos, Plateau state, Nigeria \\ DOI: 10.29322/IJSRP.11.09.2021.p11704 \\ http://dx.doi.org/10.29322/IJSRP.11.09.2021.p11704
}

\begin{abstract}
Governance is a key factor in guiding successful sustainable programmes because it is normative by nature and requires collective action. Partipatory e-Backcasting (pBC) becomes necessary, because it is appropriate for long-term problems which need major changes and long-term solutions such as sustainable city challenges. For pBC participation and extent of inputs constitutes the main plan. Nigerian cities' development measures have consistently failed which has been linked to lack of adequate citizen's active engagement. The aim of the study is to integrate and encourage stakeholders in an enhanced participatory ebackcasting approach with respect to e-Gov services which is limited towards the practical outcome of participatory ebackcasting. The study adopted qualitative research methods using participatory online approach which is basically the primary source of data collection. To achieve this, the study builds on step by step framework of conventional backcasting strategic planning method by bridging it with interactive online platforms like social and non-social media tools (WhatsApp, Facebook, Blog and Email, SMS, LinkedIn) in building up strategies for achieving a sustainable participatory dimension to the study. Out of a total of 1644 persons contacted through chain referral, only about 644 contacts gave initial consent but at the point of the four iterations only 302 persons actually participated online. WhatsApp tool recorded the highest number of participants at a total of 161 at a time, compared to email (15), Facebook (58) and blog (9). Based on the analysis of the information obtained, it was observed that there is great potential for stakeholder's participation bottom-up if adequately managed. It is recommended that direct broad participation of a large spectrum of stakeholders residing either in Nigeria and/or in the Diaspora ranging from 18 to 65 years of age be integrated to achieve well envisioned sustainable cities in Nigeria.
\end{abstract}

Index Terms- electronic governance, governance, inclusive participation, sustainable city development, social media

\section{BACKGROUND}

E lectronic governance or e-governance is a two-way communication protocol which engages the use of information and communication technology (ICT) towards expediting delivery of government services (Falco and Kleinhans, 2018). It also involves the exchange of varying data and communication transactions, integration of various stand-alone systems and services as well as back-office processes and interactions within the entire government structure (Humadi, 2015; Rajiv, Amit, and Arindam, 2017).

Coursey and Norris (2008) noted that official government sites delivering information and services began appearing on the web in the mid-1990s. While e-government encompasses a broad range of activities, it mainly entails four primary representations which are - government-to-citizen (customer) (G2C), government-to-employees (G2E), government-to-government (G2G) and government-to-business/interest groups (G2B). The Government-to-government ( $G$ to $G$ ) sector represents the backbone of e-government, and it deals with data sharing and electronic exchanges of ideas between various government agencies while government-to-citizen ( $\mathrm{G}$ to $\mathrm{C}$ ) facilitates citizen interaction with government as a primary goal of any government. Ojo (2014) argues that e-government platforms increase access of local citizens to their elected representatives as well as to essential social services through the facilitation of information and communication technologies. The technology enhances effective communication between the government and the governed at the grassroots level and thus creates an opportunity for citizens to receive on-going feedback from the appropriate government channels. Sachdeva (2008) gives another dimension to $\mathrm{G}$ to $\mathrm{C}$ as Citizens-to-Government $(\mathrm{C} 2 \mathrm{G})$. This type of interaction only relates to areas where the citizen interacts with the government (such as citizens voting for their government representatives; carrying out census where residents provide information about themselves to the government, or taxation where citizens have to pay taxes to the government). For e-government services to be successful, studies such as Nour et.al. (2008) and Latifa, Wafi and Vishanth (2017) argue for e-government initiatives to be implemented logically in line with the diversity of government structures, local cultures, economic conditions, technological resources/infrastructures, citizens' trust and socio-political factors. Shim and Eom (2008) and Kurfalı et.al.,(2017) urge governments to continually appraise the effectiveness of egovernment processes, mainly as a tool for promoting good governance as well as for strengthening reform-oriented initiatives which would contribute towards enhancing relationships with citizens and facilitate more efficient monitoring and evaluation processes. E-Government can thus aid policymakers and urban development authorities in pursuit of sustainable urban development. 
Osimo (2008) noted that prevailing approaches in measuring progress in e-government implementation were rooted in an old model which was thus losing its relevance. The study argued for a new method using recent innovations in internet development called Web 2.0 and especially integrating the monitoring of progress/impact of e-Government. Millard (2008) and Alam and McLoughlin (2018) argue that Web 2.0 has helped in creating a more effective model for e-government as it offers revolutionary tools for gathering, organising and sharing information across all sectors, individuals and organisations. "Web 2.0 technologies" constitute a platform for a diverse range of social media through which individuals can interactively engage as active participants (individuals can create, organise, edit, combine, share, comment and rate Web content through these media tools). The platform also involves interacting and linking to each other as well as operating social networks for diverse needs/goals. The leading Web 2.0 technologies at present include platforms such as Google, Weblogs, Wikipedia, Myspace and Second Life, as well as social networking hubs, such as Facebook, Myspace. The technology/hub also comprises people-based communication modes for chatting, chat groups, and photo-sharing platforms (such as Flickr). Video casting and sharing such as YouTube as well as audio-sharing (e.g. podcasts), and mashups, widgets, virtual worlds, microblogs (such as Twitter), social annotation and bookmarking of Web sites, and many more Ayodele (2013) and Financial Nigeria (2016) (Chun et.al. 2010, Akintola, Yusuf and Odutayo, 2017). The technologies have become widely adopted and thus in turn are starting to, influence e-governance approaches to the use of the ICT tools for e-government/e-participation.

Motihar (2015) claims that e-governance is carried out by the governed, for the governed and of the governed. The primary rationale for e-governance would therefore be to effectively and efficiently ensure that services intended to reach the targeted citizens are effectively delivered. The key criteria for measuring the success of e-governance would be security, functionality, and transformation (Roman, 2013). Nour et.al. (2008) are of the opinion that e-governance platforms have been able to compensate for significant lapses in conventional governance especially through facilitating efficiency and reducing paperwork. The technology has therefore contributed to a more satisfied citizenry and widespread interest in e-governance applications while promising further potential benefit of providing clear, transparent, interactive, easy to implement and just solutions within faster time frames. Differentiating between claims focuses on developed versus developing country experiences-the significance of the digital divides

Molinari and Ferro (2009) affirm that e-government/eparticipation and social media play an important part in the construction and diffusion of identity for citizens, as one of the valuable means of creating a shared sense of belonging. In spite of credible success in the deployment tools of e-governance, it still faces many challenges as it evolves. Stakeholders' access to this essential social service requires diverse communication technology infrastructure services which would enhance effective communication amongst citizens and their government. This raises the affordability concern, both in terms of hardware, apps and data resources as factors limiting active participation as observed among participants' experiences during the application process of the prototype e-backcasting. The first step towards e- governance is to develop tools and approaches, guided by a comprehensive understanding of e-governance services sought by the diverse range of different stakeholder groups. The first strategic issue for this study was to adopt the use of Web 2.0 social media tools that aided the understanding sought through engaging a broad range of different stakeholders under a prototype-guided action research design.

\section{METHODS AND MATERIAL}

The first step in this online approach is to develop tools and approaches for understanding the benefits sought by a wide range of different stakeholder groups in e-government which is important in the development of knowledge and practice, policy, and evaluation with respect to broad based stakeholder engagement with, and participation in this research. "Web 2.0 or Social Web Technologies" is used to engage participants because it is the collection of different social media through which individuals can actively participants in creating, organizing, editing, combining, sharing, commenting, and rating Web content as well as forming a social network through interacting and linking to each other. To achieve this for this research and to ensure the use of a common platform across different initiatives that will be helpful in the course of the study, 4 online instruments (WhatsApp, Facebook, Blog and Emails) were adopted to help integrate different stake holder's inputs horizontally and vertically in an interactive manner. After several iterations, data were collected and analysed with results presented in tables and figures.

\section{RESULTS AND FINDING}

\section{Recruitment and Participation}

Data on the degree of involvement across all three platforms are shown in Tables 1, 2, 3 and 4. The WhatsApp tool recorded the highest number of participants at a total of 161 at a time, compared to email (15), Facebook (58) and blog (9). This number of participants for the WhatsApp was attributed to the cheaper rate charged and less data required to participate and convenience of usage as it now performs very similar functions as Facebook. All these factors contributed towards the lower usage of the other platforms. The email, blog and Facebook recorded relatively fewer participants because of inhibiting factors such as the high cost of airtime, the process required in logging into the websites and link in order to participate, especially when coupled with the effect of the recession and increased dollar exchange rate. Out of a total of 644 contacts made via social and non-social media tools, only about 302 persons gave consent and participated (see Table 1). Out of the 302, about 33 persons subsequently opted out or exited without prior notification to the researcher. 13 of those who exited expressed lack of ability to engage in public group discussions and asked for alternative means of engagement, if any. The other set of 10 left because of the difficulty in effectively airing their opinion, while another 13 left without explanation. This led to several adjustments in approach, in writing and presentation of topics for better comprehension by all. There were also other challenges which negatively impacted on the extent of participation. For example, about 23 participants who reside outside Abuja, complained of not being able to contribute 
effectively to the various topical issues raised, as they were not familiar with the city vision, developmental process, and its historical context. Others reported challenges with their handsets. At the onset of the exercise, it was established that 45 participants were not connected on-line. Subsequently to further inquiry as to why, 5 attributed their non-participation to their phones being stolen, ten had their phones changed while eight changed their lines to other networks aside from the one they had earlier been on, 10 had faulty phones/handsets, and 6 had out-of-network coverage issues. After follow-up calls and contacts were made, a total of 27 prospective participants were able to rectify their challenges, but 18 others had to be removed from the platform because they were not reachable (see Table 2 and 4).

\section{Email platform (first iteration)}

The schedules below refer to activities or plans set out within the time frame allotted. Responses reflect the number of feedback/interactions recorded from participants for every activity. Daily records of active respondents showed that five persons were active at the first schedule with 6,2 and 2 active participants for schedule II, III and IV respectively while 21, 15, 13, and 11 participants make up the number of passive respondents (see Table 1 and Figure 1). At the onset of the piloting stage, the first week had only four responses constituted of 2 respondents and 2 promises. Subsequently, in order to get participants to respond

to emails, 3 reminders were sent to 26 consenting participants; the first was sent to 21 participants the $1^{\text {st }}$ week of commencement of exercise out of which 5 responses were received; 4 responded, one participant promised to respond while 16 did not respond. The second reminder was sent to the 16 participants on the $2^{\text {nd }}$ week. 2 responses were received; 1 apologised for inability to give the reply on time, the others promised to respond while 14 did not respond to the emails sent. The third reminder was sent to the 14 who were yet to respond on the as at the third week of interaction. This third reminder yielded 3 responses, 1 apology, and 2 responses while the remaining 11 to date never replied to the emails. To an extent, sending participants' regular reminders encouraged continued participation as a total of 15 people responded out of the 26 consenting-participants thus making $58 \%$ rate of participation (see Table 1).

Source: Adapted from Achuenu (2019)

Table 1: E-mail schedules and extent of participation

\begin{tabular}{|c|c|c|c|c|c|c|c|c|c|c|c|}
\hline \multirow{2}{*}{\multicolumn{3}{|c|}{$\begin{array}{l}\text { Recruitmen } \\
\text { t/Schedule } \\
\left(1^{\text {st }}-30^{\text {th }}\right. \\
\text { Sept. 2016) }\end{array}$}} & & \multicolumn{2}{|c|}{ Schedule I } & \multicolumn{2}{|c|}{ Schedule II } & \multicolumn{2}{|c|}{$\begin{array}{l}\text { Schedule } \\
\text { III }\end{array}$} & \multicolumn{2}{|c|}{$\begin{array}{l}\text { Schedul } \\
\text { e IV }\end{array}$} \\
\hline & & & & \multicolumn{2}{|c|}{$1^{\text {st }}$ week } & \multicolumn{2}{|c|}{$2^{\text {nd }}$ week } & \multicolumn{2}{|c|}{$3^{\text {rd }}$ week } & \multicolumn{2}{|c|}{ 4thweek } \\
\hline 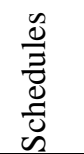 & & 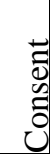 & 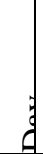 & 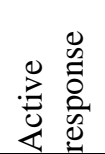 & 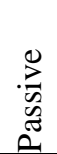 & 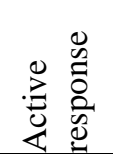 & 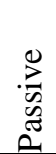 & 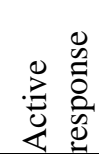 & 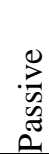 & $\stackrel{0}{0}$ & 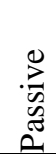 \\
\hline $\begin{array}{l}1^{\mathrm{st}} \mathrm{W} \\
\text { eek }\end{array}$ & $\begin{array}{l}1 \\
0\end{array}$ & 8 & 1 & 02 & 24 & 00 & 21 & 00 & 15 & 00 & 13 \\
\hline $\begin{array}{l}2^{\text {nd }} \\
\text { wee } \\
k\end{array}$ & $\begin{array}{l}1 \\
0\end{array}$ & $\begin{array}{l}0 \\
7\end{array}$ & 2 & 01 & 23 & $\begin{array}{l}03 \\
\text { respo } \\
\text { nse }\end{array}$ & 18 & 01 & 14 & 00 & 13 \\
\hline $\begin{array}{l}3^{\text {rd }} \\
\text { wee } \\
k\end{array}$ & $\begin{array}{l}1 \\
0\end{array}$ & $\begin{array}{l}0 \\
6\end{array}$ & 3 & $\begin{array}{l}01 \\
\text { promi } \\
\text { se }\end{array}$ & 22 & $\begin{array}{l}\text { 01res } \\
\text { ponse }\end{array}$ & 17 & $\begin{array}{l}01 \\
\text { apol } \\
\text { ogy }\end{array}$ & 13 & 00 & 13 \\
\hline \multirow[t]{2}{*}{\begin{tabular}{|l|}
$4^{\text {th }}$ \\
wee \\
$k$
\end{tabular}} & $\begin{array}{l}1 \\
0\end{array}$ & $\begin{array}{l}0 \\
5\end{array}$ & 4 & 01 & 21 & $\begin{array}{l}01 \\
\text { apolo } \\
\text { gy }\end{array}$ & 16 & 00 & 13 & 00 & 13 \\
\hline & & & 5 & $\begin{array}{l}01 \\
\text { promi } \\
\text { se }\end{array}$ & 20 & $\begin{array}{l}01 \\
\text { promi } \\
\text { se }\end{array}$ & 15 & 00 & 13 & 00 & 13 \\
\hline \multirow[t]{2}{*}{$\begin{array}{l}\text { Tota } \\
1\end{array}$} & $\begin{array}{l}4 \\
0\end{array}$ & $\begin{array}{l}2 \\
6\end{array}$ & 6 & 0 & 20 & 00 & 15 & 00 & 13 & 01 & 12 \\
\hline & & & 7 & 0 & 20 & 00 & 15 & 00 & 13 & 01 & 11 \\
\hline \multicolumn{3}{|c|}{ Total } & & $05 / 26$ & $\begin{array}{l}21 \\
12 \\
6\end{array}$ & $06 / 21$ & $\begin{array}{l}15 \\
/ 2 \\
1\end{array}$ & $\begin{array}{l}02 / 1 \\
5\end{array}$ & $\begin{array}{l}13 \\
/ 1 \\
5\end{array}$ & $\begin{array}{l}02 \\
/ 1 \\
3\end{array}$ & $\begin{array}{l}11 \\
/ 1 \\
3\end{array}$ \\
\hline \multicolumn{3}{|c|}{ Average } & & $\begin{array}{l}05 / \mathrm{sc} \\
\mathrm{h} .=1\end{array}$ & $\begin{array}{l}21 \\
14 \\
=5\end{array}$ & $6 / 4=2$ & $\begin{array}{l}15 \\
14 \\
=4\end{array}$ & $\begin{array}{l}02 / 4 \\
=1\end{array}$ & $\begin{array}{l}13 \\
14 \\
=3\end{array}$ & $\begin{array}{l}02 \\
14 \\
=1\end{array}$ & $\begin{array}{l}11 \\
14 \\
=3\end{array}$ \\
\hline
\end{tabular}




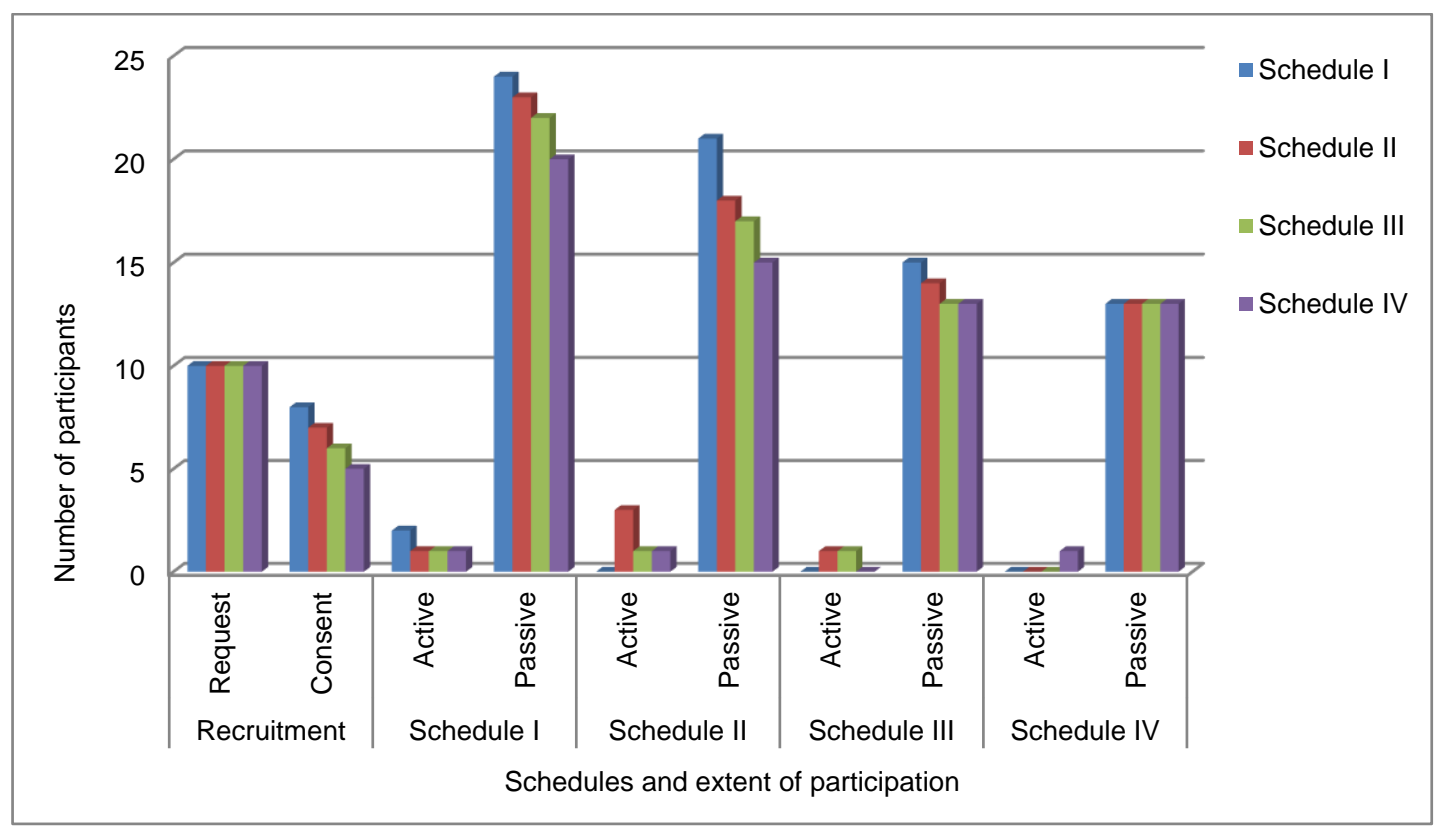

Figure 1: Schedules and extent of participation in the email platform Source: Adapted from Achuenu (2019)

Unlike the WhatsApp and Facebook platforms, the email platform does not allow one to note first-hand who exits the group, is removed or violates the rules of participation. Participants choose to either respond to the mail or ignore it. Below are a few excerpts from participant responses in their own word after reminders:

Email Respondent 1: Hi Stella, I will do it tomorrow. I just came back after about 2 months being away.

Email Respondent 2: Hi Stella, Ok please. I will try and do that very soon. Best wishes

Email Respondent 3: Hi Stella, Sorry about the mix up. I missed applied response to your questions which would have been done on a different request. Disregard the one I sent, I will make time.

Email Respondent 4: Okay. Madam, I have stated but not yet finished. I will try to finish soon.

The major challenge with the use of emails has to do with the fear of having the computer send emails as spam to participant's emails, thereby missing out on the target and thus resulting in the loss of prospective participants. About three potential participants were lost due to this challenge. Another challenge was that many of the targeted participants did not show interest and as such never responded to messages sent even after they had given their consent. For this platform, networking and the level of inclusiveness of participation was not the focus, instead the testing the applicability, workability, making changes and adjustment where needed was the primary focus. Notably, the email platform does not facilitate effective networking when compared to WhatsApp and Facebook tools.

\section{Facebook (second iteration)}

The five schedules of activities saw participation rising from 18 in the first week to 24 the second week and dropping to 23 by the fifth week. From the beginning to the fifth week, there were silent members, otherwise known as observers, rising from two to 33, showing the same trend with those of WhatsApp. Cumulatively, recruitment shows consistent rise in consenting participants facilitated by the networking approach, as there were noticeably gradual increases in recruitment from the first schedule to the last; 20, 41, 43, 44 and 49 (see Table 4 and Figure 2). The gradual increase in participation between first, second and third schedules in daily recruitment has been the trend in all platforms and reasons are that participants at first are excited, but later give way to distractions and other personal issues. The gradual decrease is also attributed to lack of patience particularly as it had nothing to do with socialising.

Participants see the entire process as an academic exercise and because of that notion, they were not able to dedicate quality time and input to the entire process. The total numbers of participants recorded at the end of the fifth week were 55 in number out of a total of 76 recruited (see Table 2). Cumulatively, an average of 45 persons were recruited for every schedule while on average, 5 persons exited the group. A total of 23 participants exited the group for the following reasons: 9 participants were removed based on the violation of the guiding policy while 14 others voluntarily opted out. This makes the platform second in terms of with the highest number of exiting participants after those in the WhatsApp platform. The total number of exits recorded on Facebook is seen as high because the number of exits when compared to the total number of participants is about $33 \%$ which is quite high. 
Table 2: WhatsApp schedule and extent of participation

Source: Adapted from Achuenu (2019)

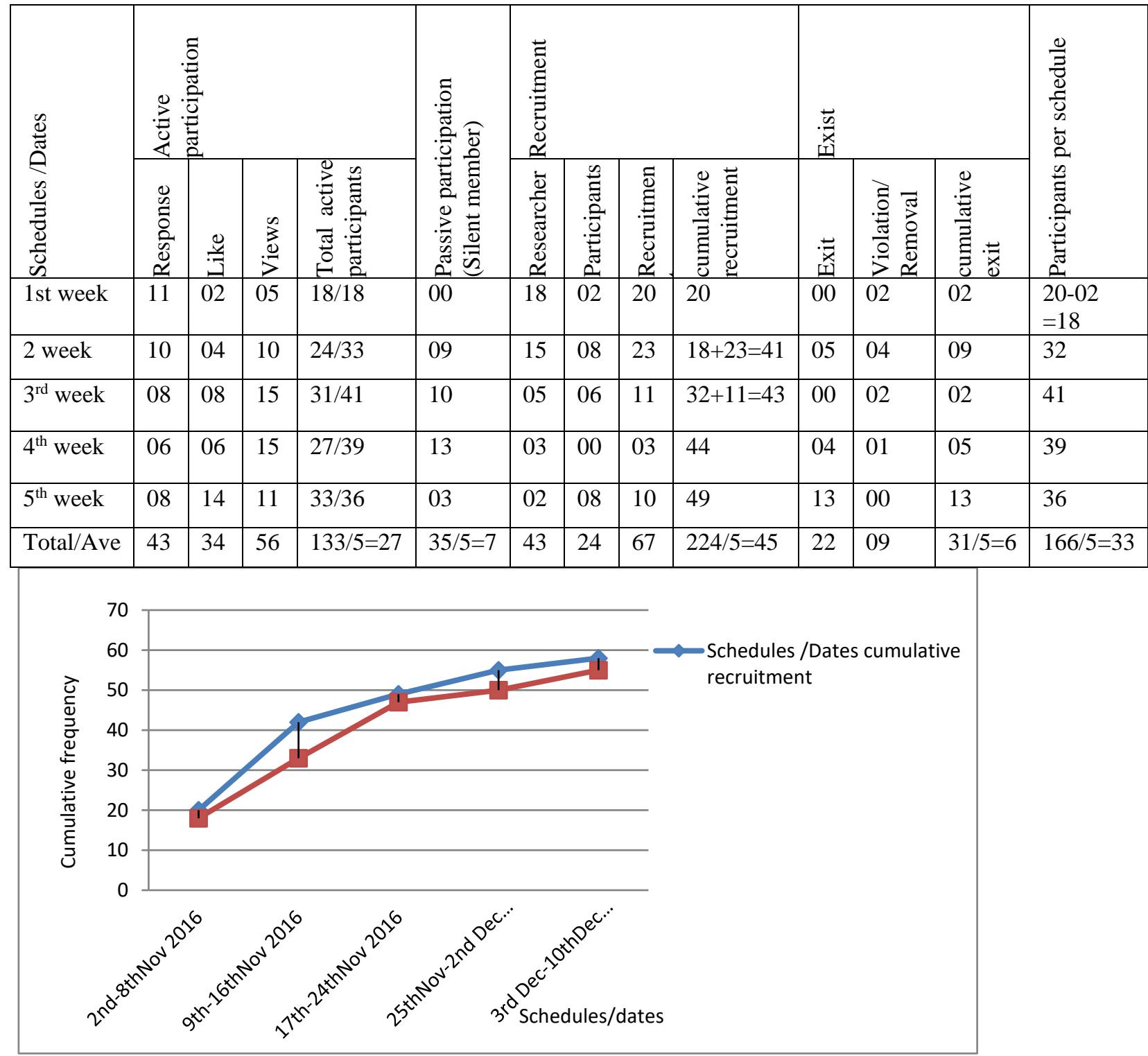

Figure 2: Cumulative recruitment and participation per schedule for Facebook

Source: Adapted from Achuenu (2019)

Participants see the entire process as an academic exercise and because of that notion, they were not able to dedicate quality time and input to the entire process. The total numbers of participants recorded at the end of the fifth week were 55 in number out of a total of 76 recruited (see Table 2). Cumulatively, an average of 45 persons were recruited for every schedule while on average, 5 persons exited the group. A total of 23 participants exited the group for the following reasons: 9 participants were removed based on the violation of the guiding policy while 14 others voluntarily opted out. This makes the platform second in terms of with the highest number of exiting participants after those in the WhatsApp platform. The total number of exits recorded on Facebook is seen as high because the number of exits when compared to the total number of participants is about $33 \%$ which is quite high.

Participants were removed by the administrator due to the violation of the guiding policy. Those removed got into the habit of posting pictures, unrelated political-talks or some religious posts, most of which were out of the scope of the research and against the policy of the group. 2 persons were removed in the first week at the same instance, while the remaining seven were repeatedly warned three times before each removal. Facebook is one of the sites most visited by participants between the ages of $35-49$ years, and as compared to the ages reflected in the readings appraised for this research and particularly Ayodele (2013) and Financial Nigeria (2016) for the related argument. 
From the first week, those tagged as viewers (passive participants) increased from 5 viewers to 15 within a period of four weeks and suddenly went down to six viewers. This was the same for those 'likes' as some topics had more likes than others. For example, the topics for the third week had 8 'likes'. The initial increase in likes and views were attributed to the fact that participants saw some topics as very interesting and educational and others as boring and requiring critical thinking.

\section{Word press blog platform (third iteration)}

The blogging activity commenced and concluded within a total of 4 months (16 weeks). It recorded the lowest number of participants out of approximately 30 participants contacted; it had just 9 consenting (see Table 3), even after the timing for the exercise was extended beyond the initially proposed timeframe. A key to participation under this platform hindrance was the overwhelmingly high pressure with regards to collating and managing the WhatsApp platform, as the process for both platforms overlapped time wise. To the benefit of the study, WhatsApp process picked up faster than expected and enjoyed high participation in terms of more posts and repeat posts. This resulted into a deficiency in attention given to the blog, which operated in a completely different way, as it has no tool to track who exited or was removed from the group. Instead, interested participants are only required to log on through the blog link and insert their comments. The comments were directly linked to the researcher's email where they could be accessed.

Table 3: Blog schedules, recruitment and extent of participation

\begin{tabular}{|l|l|l|}
\hline Schedules/Dates & $\begin{array}{l}\text { Contacts } \\
\text { made }\end{array}$ & $\begin{array}{l}\text { Consents/response } \\
\text { received }\end{array}$ \\
\hline $1^{\text {st }} 4$ weeks & 10 & 03 \\
\hline $2^{\text {nd }} 4$ weeks & 12 & 04 \\
\hline $3^{\text {rd }} 4$ weeks & 7 & 01 \\
\hline $4^{\text {th }} 4$ weeks & 6 & 01 \\
\hline Total participants' & 30 & 09 \\
\hline
\end{tabular}

Source: Adapted from Achuenu (2019)

\section{WhatsApp (fourth iteration)}

For the first week, a total of 117 consenting participants were recorded. The total number of participants for each week is obtained from the total participants from previous week plus those recruited for the new week minus the total number of exits recorded for the new week (see Table 4). The e-backcasting started in the first week with 117 people, the second week had a total of 173 and by the eighth schedule/week 161 consenting participants had been retained. The knowledge of the cumulative daily recruitment gives an idea as to the number of recruitments due both to the researcher's and participants' efforts to attract people and encouraging them to participate daily (see Table 2). For the entire exercise, 151 people were recruited by the researcher while participants recruited 58 through their own networks. On the average, 56 persons were actively engaged in the schedules. The first week records 91 active participants out of a total of 117 , but by the seventh the number of active participants dropped to 15 participants.

Table 4: WhatsApp platform recruitments, schedules and participation issues

\begin{tabular}{|c|c|c|c|c|c|c|c|c|c|c|c|}
\hline \multirow[b]{2}{*}{ 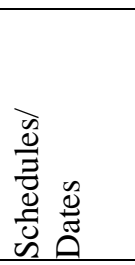 } & \multirow{2}{*}{ 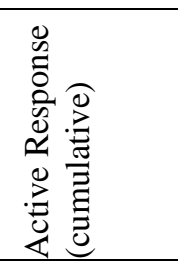 } & \multirow{2}{*}{ 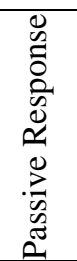 } & \multicolumn{4}{|c|}{ Recruitment } & \multicolumn{3}{|c|}{ Exit } & \multirow[b]{2}{*}{$\frac{\stackrel{0}{0}}{\frac{\pi}{0}}$} & \multirow{2}{*}{$\begin{array}{l}\text { Total number of participants per } \\
\text { schedules }\end{array}$} \\
\hline & & & 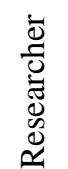 & 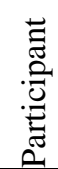 & 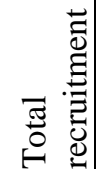 & 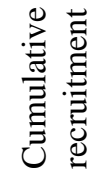 & 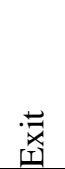 & $\begin{array}{l}\text { 중 } \\
0 \\
0 \\
0 \\
0\end{array}$ & $\begin{array}{l}\frac{\pi}{x} \\
\frac{\pi}{0} \\
0 \\
0\end{array}$ & & \\
\hline $1^{\text {st }}$ week & 91 & 26 & 99 & 24 & 123 & 123 & 06 & 00 & 06 & 01 & 117 \\
\hline $2^{\text {nd }}$ week & 68 & 99 & 39 & 16 & 55 & 178 & 04 & 01 & 05 & 01 & 173 \\
\hline $3^{\text {rd }}$ week & 94 & 80 & 10 & 06 & 16 & 194 & 05 & 04 & 09 & 02 & $189-9=180$ \\
\hline $4^{\text {th }}$ week & 68 & 102 & 01 & 00 & 01 & 195 & 04 & 01 & 05 & 01 & 176 \\
\hline $5^{\text {th }}$ week & 33 & 118 & 01 & 10 & 11 & 206 & 06 & 02 & 08 & 02 & 179 \\
\hline $6^{\text {th }}$ week & 55 & 99 & 01 & 02 & 03 & 209 & 00 & 00 & 00 & 00 & 182 \\
\hline $7^{\text {th }}$ week & 15 & 132 & 00 & 00 & 00 & 209 & 00 & 06 & 06 & 00 & 176 \\
\hline $8^{\text {th }}$ week & 24 & 99 & 00 & 00 & 00 & 209 & 00 & 15 & 15 & 00 & 161 \\
\hline Total & 448 & 755 & 151 & 58 & 209 & 1523 & 25 & 29 & 54 & 07 & 1350 \\
\hline Average & $\begin{array}{l}448 / 8 \operatorname{sch}=5 \\
6\end{array}$ & 94 & 19 & 7 & 26 & 217 & 3 & 4 & 7 & 1 & 169 \\
\hline
\end{tabular}

Source: Adapted from Achuenu (2019)

*Passive Response $=$ Total number of participants for each schedule minus active respondents e.g. 173-68=105

$*$ Cumulative recruitment $=$ Previous recruitment plus the new schedule recruitment e.g. $123+55=178$

*Total number of participants for each schedules $(\mathrm{sch})=$. Total participants from previous Schedule Plus new schedule recruitment minus new schedule exits e.g. $117+55-05=173$

*Active Response $=$ Cumulative participation per schedule 


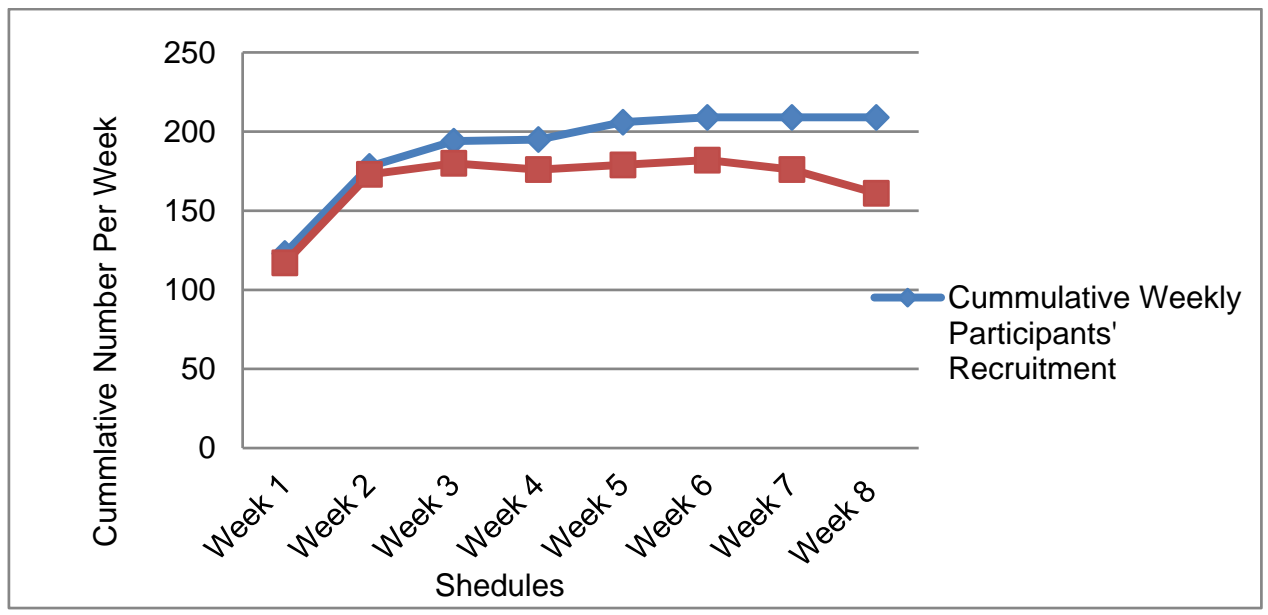

Figure 3: Cumulative recruitments and participation per stage for WhatsApp

Source: Adapted from Achuenu (2019)

In assessing the weekly recruitment, the researcher had the highest recruitment for week 1 and 2, with 99 and 39 people recruited while participants had 24 and 16 recruitment respectively for the two weeks. As at the seventh and eighth-week, recruitment stopped as participants felt the exercise was running to an end, and therefore did not need any more recruitment. In order to avoid participants becoming bored and opting out faster than they were recruited, the researcher decided to put a stop to recruitment to allow space for participants to attend to their activities.

\section{Key limitations to effective participation}

Table 5 presents the key limitations to effective participation (both in terms of those consenting as well as the on-going contributions across the various platforms. Two reasons explain why total number of recruitments/interactions amongst participants dwindled and fluctuated. These are:

- Since participation is on a voluntary basis, as soon as phase two of the e-backcasting started, particularly at the revisioning/backcasting stage (see Table 2), the interest of participants dropped due to the critical thinking and technicalities involved while many others preferred to remain passive. That explains why the number of passive participants increased from 26 in the first week to 132 by the seventh week

- Coincidently, participants became very busy pursuing their personal activities and quite a number preferred to remain passive instead of exiting the group. The fluctuation in the total number of participants also indicates the extent of exits, removals due to continued violation of guiding principles even after repeated warnings by the administrators while some requested to be removed. This challenge cuts across the other three platforms, especially Facebook. For instance, the excerpts below give an example of cases where people requested to be removed (note that most participants responses have not been edited)

Respondent WhatsApp: So sorry jare! You know me and group chats! I will respond but I would have to plead with you to let me off o! It seems I am not able to commit to it. I hardly read the chats and can't follow the line of questioning! So much to do in the office!. The truth is I do not want to give opinions that are not carefully thought out and because of a lack of time; I cannot follow the train of thought on it!

As shown in Table 5, 17 other factors were cited as key contributors to hindering active participation and also inhibiting consistency in the total number of as well as quality participants' by schedule. From the pilot study, participants' reasons for not effectively responding within the timeframe allotted for each session include being very busy, wrong email, redundant and inactive emails (which resulted to eight sent email messages being returned as undeliverable). Table 5 shows that 20 respondents complained of never having been to Abuja before (and so could not effectively contribute) while 21 prospective participants complained of residing outside Nigeria and unfamiliar with issues concerning Abuja (and thus lacked adequate knowledge about the city's vision and plans). Similar constraints cut across all the four platforms.

Table 5: Constraints limiting participation

\begin{tabular}{|c|c|c|c|c|c|}
\hline Limitations & Facebook & WhatsApp & $\begin{array}{l}\text { E- } \\
\text { mail }\end{array}$ & Blog & Total \\
\hline Poor Internet & 2 & 4 & - & 1 & 7 \\
\hline Sick & 2 & 4 & - & - & 6 \\
\hline $\begin{array}{l}\text { Phone } \\
\text { problem }\end{array}$ & 4 & 12 & - & 1 & 15 \\
\hline Busy at work & 3 & 11 & 2 & 1 & 17 \\
\hline $\begin{array}{l}\text { Lacked } \\
\text { confidence/all } \\
\text { interaction } \\
\text { were done in } \\
\text { English }\end{array}$ & - & 6 & - & - & 6 \\
\hline Busy at school & 5 & 9 & 4 & - & 18 \\
\hline $\begin{array}{l}\text { Inadequate } \\
\text { knowledge on } \\
\text { Abuja vision } \\
\text { and plans, } \\
\text { never visited, }\end{array}$ & 4 & 6 & 2 & 1 & 13 \\
\hline
\end{tabular}




\begin{tabular}{|c|c|c|c|c|c|}
\hline $\begin{array}{l}\text { nor resident in } \\
\text { Nigeria }\end{array}$ & & & & & \\
\hline $\begin{array}{ll}\text { Study visa } \\
\text { expiration and } \\
\text { delayed } \\
\text { renewal }\end{array}$ & - & 2 & - & - & 2 \\
\hline $\begin{array}{l}\text { Not ready to } \\
\text { comment }\end{array}$ & 2 & 8 & - & - & 10 \\
\hline $\begin{array}{l}\text { Bounced } \\
\text { Emails }\end{array}$ & 0 & 0 & 0 & 8 & 8 \\
\hline Busy & 2 & 7 & 3 & - & 12 \\
\hline $\begin{array}{l}\text { Unemployed } \\
\text { and financially } \\
\text { incapacitated }\end{array}$ & 1 & 4 & - & - & 5 \\
\hline $\begin{array}{l}\text { Not stable } \\
\text { emotionally } \\
\text { and physically }\end{array}$ & - & 3 & - & - & 3 \\
\hline Travelled & 4 & 5 & 2 & - & 11 \\
\hline $\begin{array}{ll}\text { Busy and } \\
\text { Unstable }\end{array}$ & 4 & 5 & 1 & - & 10 \\
\hline $\begin{array}{l}\text { Don't reside in } \\
\text { the country }\end{array}$ & 10 & 8 & 2 & 1 & 21 \\
\hline $\begin{array}{l}\text { Rigour of } \\
\text { participation }\end{array}$ & 11 & - & - & 4 & 15 \\
\hline Total & 54 & 94 & 16 & 17 & 181 \\
\hline
\end{tabular}

Source: Adapted from Achuenu (2019)

Fifteen participants who had initially given consent in the Facebook and blog forum complained of not being able to dedicate time to follow up with the sessions due to the rigour involved. Some participants were not able to participate because they felt the difficulty involved with using Facebook was too much, while others said that they could not afford sufficient data-bundles on their phones due to the recession. A few others reported that their inability to participate was due to the limited time given to respond and further suggested that more time be provided to enable quality-participation.

The researcher could not provide more time since the study is time-bound but also because those that were very active were neither patient nor willing to allow for more time, since they had other personal issues to attend to. 5 people blamed their inability to participate effectively on unemployment and lack of good sources of income. About 10 participants had issues that hindered their participation, which they did not reveal/report. 13 participants complained about the limitation caused by the timing given to respond to each exercise. A few excerpts in participants' words stating reasons why they could not give inputs as much as they would have loved to are as follows:

- Sick

- Participant 1: Flu kept me in this week

- Respondent 2: Sorry I haven't responded yet. I am just recovering from a bout with fever. I will go through and respond accordingly

- Phone problem

- Respondent 3: I just replaced my handset last week as my old phone crashed; you may have to re-send the link to the blog again
- $\quad$ Respondent 16: I will comment soon, I am having issues with my phone. Can't type, I formatted my phone twice just this week, so it's taking me more time to restore things back on my phone

- Respondent 11: Okay will comment soon. I belong to too many groups and their various activities are consuming my battery power a lot. But all the same, I have been following up on the group chat

- Respondent 20: I wanted to send a message some days back, and I was told I could not send any word that I have been removed from the group, but I guess its network

\section{- Busy at work}

- Respondent 3: I'm at work at the moment. Work's the reason I've not been able to make any contribution yet, please. Don't even have time enough to read much of other members' opinions

- Lacked confidence/all participation was done in English

- $\quad$ Respondent 4: Send me the question through this number. I find it difficult to join multi-chatting sometimes

- Respondent 8: My sister. I'm somewhat being schooled in the forums than contributing. I don't know much about Abuja and its planning cynics; I, however, will participate on the population dimensions when I'm less busy

- Busy at school

- Respondent 5: I'm also working on my master's degree project. I'm working on chapter five. That is why I have not been able to contribute

- Respondent 9: Am alright, just that we are writing exams right now, I mean Enugu state university of technology

- Respondent 17: Sorry for the long silence, marking student exam scripts has taken up most of my time. I will say something on the topics soon

- Busy

- Respondent 6: I can't participate in the questionnaires, for now, time does not permit me. I'm busy with quite some projects, and I cannot apply my mind to your task for now. I would have loved to help. Hope you understand

- Respondent 12: well I could not read the debates or other contributions. On my way back to Nigeria from the Niger Republic from international boundary synchronization meeting

- Respondent 7: I am not active at the moment on both WhatsApp and Facebook

- Respondent 14: I responded once but am currently occupied with a campus design; hope to make contributions this weekend

\section{- Never visited, nor resident in Nigeria}

- Respondent 10: I cannot participate or make honest contributions because am not a resident in Abuja which is the location of being studied, this platform is educative as much, and it demands constructive input. My worry is if I have to make contributions then my ideas will be based on assumptions.

\section{- Poor Internet}

- Respondent 13: Sorry I've been unstable. I'm doing some work in a remote village in Bauchi and there are no stable networks here. I would have loved to be more active, but there are so many issues with internet network in this village 


\section{- Unemployed and financially incapacitated}

- Respondent 15: Morning it has not been easy with me financially, no job and so lack motivation, but I promise to improve because the forum has impacted a lot in me

\section{- Study visa expiration and delayed renewal}

- Respondent 19: Busy trying to see if I can submit my thesis before coming back home soon, my permit expired on December 31. I applied for critical skill since October but no response from Directorate of Home Affairs. With this Xenophobia attack, we were not allowed to work without a valid permit

These feedbacks from participants enabled the researcher to improve and make changes on the second, third and fourth iterations and thus improved on the response rate and participation. Some of the feedback was related to the time taken to participate, and the technicality of questions asked which thus made participation a time-consuming process. The respondents suggested that long, unclear and unfamiliar items should be adjusted while some of the issues for consideration should be addressed in order of importance, in order to improve on the practical application of the approach next time.

\section{CONCLUSION}

E-Governance uses modern information and technologies such as internet, digital television mobile etc for effective, efficient and transparency in information and communication. In addition, more complex services, such as the interaction with public servants or (electronic) full case handling are becoming increasingly common in public e-services delivery. E-government is increasingly becoming an important public service tool of many governmental departments around the world as an important measure for enhancing citizen access to government services and expediting the delivery of services to citizens (Kim et al., 2009). Thus e-backcasting through e-govt mechanism has the benefit of providing clear, transparent, interactive, easy to implement and just solutions in the quickest possible timeframe (Stragier et al., 2010, Humadi, 2015)

\section{REFERENCES}

[1] Achuenu, A. S. (2019). Adaptability of Participatory Backcasting to eBackcasting for Inclusive Sustainable City Visioning for African Cities: A Prototyped Study for Abuja, Nigeria. A Thesis Submitted to the Faculty of Engineering and the Built Environment, University of Witwatersrand, Johannesburg, in Fulfillment of the Requirements for the Degree of Doctor of Philosophy, Johannesburg,

[2] Achuenu, A. S. and Irurah, D. (2016). Backcasting Approach to the revisioning of a sustainable desirable future for Abuja, Nigeria, Regional urbanism in the era of Globalization, Proceedings of Centre for Urban Design, Architecture and sustainability (CUDAS), Huddersfield, Uk, 3-5th February.

[3] Chun, S.A., Shulman, S., Sandoval, R. and Hovy, E., (2010). Government 2.0: Making connections between citizens, data and government. Information. Polity 15, Url:http://cimic.rutgers.edu/ soon/papers/2010/ip2010

[4] Colesca, S.E. and Dobrica, L., (2008). Adoption and use of e-government services: the case of Romania. J. Appl. Res. Technol. 6. Url: $\mathrm{http} / / \mathrm{dl}$.acm.org/citation,cfm?id=2595295
[5] Coursey, D. and Norris, D.F., (2008). Models of e-government: Are they correct? An empirical assessment. Public Adm. Rev. 68, 523-536. doi: 10.1111/j.1540-6210.2008.00888.x

[6] De Kool, D. and Van Wamelen, J., (2008). Web 2.0: a new basis for egovernment?, in: Information and Communication Technologies: From Theory to Applications, 2008. ICTTA 2008. 3rd International Conference on. IEEE, pp. 1-7. doi:10.1109/ICTTA.2008.4529946

[7] Elsheikh, Y., Cullen, A. and Hobbs, D., (2008). e-Government in Jordan: challenges and opportunities. Transform. Gov. People Process Policy 2, 83103. doi:http://dx.doi.org/10.1108/17506160810876176

[8] Humadi, W.Z.M. Al-, (2015). E-Governance for Voter Data Collection and Verification. Eur. Acad. Res. III. Url:http://euacademic.org/upload Article/1594

[9] Kim, S., Kim, H.J. and Lee, H., (2009). An institutional analysis of an egovernment system for anti-corruption: The case of OPEN. Gov. Inf. Q. 26, 42-50. doi:10.1016/j.giq.2008.09.002

[10] Millard, J., (2008). eGovernment measurement for policy makers. Eur. J. EPractice $4, \quad 19-32$ Url:http://citeseerx.ist,psu.edu/viewdoc/download/doi=10.1.475.80957\&rep $=$ rep1\&type

[11] Molinari, F. and Ferro, E., (2009). Framing Web 2.0 in the process of public sector innovation: Going down the participation ladder. Eur. J. EPractice 9 20-34.ISSN:1988-625X, http://www.etudasportal.gov.hu/download/attachments/7995452

[12] Motihar, K., (2015). Munni of all Trades: E-governance for a brighter future! Munni Trades. Url: http://munniofalltrades.blogspot.com/2015/03/egovernance-for-brighter-future.html

[13] Nour, M.A., AbdelRahman, A.A. and Fadlalla, A., (2008). A context-based integrative framework for e-government initiatives. Gov. Inf. Q. 25, 448461. doi:10.1016/j.giq.2007.02.004

[14] Ojo, J.S., (2014). E-governance: An imperative for sustainable grass root development in Nigeria. J. Public Adm. Policy Res. 6, 77-89. doi:10.5897/JPAPR2013.0264

[15] Osimo, D., (2008). Benchmarking eGovernment in the Web 2.0 era: what to measure, and how. Eur. J. EPractice 4, 33-43. ISSN:1988-625X Url: http;/portal.forumpa.it/files/documents/file/portal/docuemnti_editoriale/osi moepJ.

[16] Roman, A.V., (2013). Delineating Three Dimensions of E-Government Success: Security, Functionality, and Transformation, in: Gil-Garcia, J.R. (Ed.), E-Government Success Factors and Measures: Theories, Concepts, and Methodologies: Theories, Concepts, and Methodologies. p. 171. Url: https://books.google.co.za/book/ht=en\&Ir-\&id=iqmb17ZhEFIC\&oi

[17] Shim, D.C. and Eom, T.H., (2008). E-government and anti-corruption: Empirical analysis of international data. Intl J. Public Adm. 31, 298-316. doi:10.1080/01900690701590553

[18] Stragier, J., Verdegem, P., and Verleye, G., (2010). How is e-Government Progressing? A Data Driven Approach to E-government Monitoring. J UCS 16 , 1088 Url:http://jucs.org/jucs 16 _ 8 /how is egovernment_progressing/juvcs _16_08_1075_1088_stragier

[19] van Wamelen, J., and de Kool, D., (2008). Web 2.0: a basis for the second society?, in: Proceedings of the 2nd International Conference on Theory and Practice of Electronic Governance. ACM, pp. 349-354. doi:10.1145/1509096.1509169

[20] Verdegem, P., Stragier, J. and Verleye, G., (2011). Measuring for knowledge: a data-driven research approach for eGovernment, in: Leading Issues in EGovernment Research. 83-100. Url:http://books.google.co.za/books?hl=en\&Ir=\&id=BEjM2gmTmNcC\&oi

[21] Verd, P., Stra, J. and Verle, G., (2012). data-d asuri d, in: 'Innovation in the Public Sectors and Development of E-Service'. Presented at the First international EIBURS - TAIPS conference, University of Urbino,.Url:http:// www.econ.uniurb.it/EibursTAIPS_conference_2012/session\%202.1/Verley e\%20et\%20al.

[22] Vig, S., (2012). Ensuring better corporate governance through e-governance, 2nd Edition. ed, International Journal of Marketing, Financial Services \& Management Research. IGI Global, 2008, Indiana University. Url:http://www.indianresearchjournals.com/pdf/IJMFSMR/2012 


\section{AUTHORS}

First Author - Achuenu, Ache Stella, Department of Urban and Regional Planning, University of Jos, Plateau state, Nigeria
Correspondence email: saachuenu@gmail.com1, achuenua@unijos.edu.ng 